\title{
Association of Actinomyces with Allergic Rhinitis, Adenotonsillar Hypertrophy and Chronic Recurrent Tonsillitis and Its Histopathological Findings
}

\author{
Actinomyces'in Alerjik Rinit, Adenotonsiller Hipertrofi ve Kronik Rekürren Tonsillit Ilișkisi ve \\ Histopatolojik Bulguları
}

\author{
(D) Ilke Evrim SEÇiNTi \\ Hatay Mustafa Kemal University Tayfur Ata Sökmen Faculty of Medicine, Department of Pathology, Hatay, Turkey
}

\begin{abstract}
Aim: To evaluate the prevalence of adenotonsillar Actinomyces with histopathological findings and to determine the relationship of Actinomyces with allergic rhinitis (AR), adenotonsillar hypertrophy (ATH) and chronic recurrent tonsillitis (CRT).

Materials and Methods: Histopathological sections were retrospectively analyzed in 228 patients who underwent adenoidectomy, bilateral tonsillectomy, and adenotonsillectomy. The presence of Actinomyces, cryptitis, and severity of inflammation were determined. Data were analyzed with the Statistical Package for the Social v.21.0 package software. The statistical significance level was accepted as $p<0.05$.

Results: Actinomyces was detected in 39 (17.1\%) patients. Actinomyces was seen at a similar rate in ATH and CRT ( $p=0.08)(14.6 \%$ and $24.6 \%$, respectively). The diameter of the tonsils with Actinomyces were larger than those without Actinomyces ( $p<0.01)$. The frequency of cryptitis in tonsils with Actinomyces histopathologically $(p=0.03)$ and the degree of inflammation in the surface epithelium ( $p<0.01)$ were increased. Actinomyces was found more frequently in patients with AR than in patients without AR ( $p=0.02)(25.7 \%$ and $13 \%$, respectively).

Conclusion: Our study shows that adenotonsillar Actinomyces colonization may cause ATH, CRT and AR, and AR may be one of the factors in the etiology of ATH.
\end{abstract}

Keywords: Actinomyces, adenotonsillar hypertrophy, allergic rhinitis, recurrent tonsillitis

ÖZ

Amaç: Adenotonsiller Actinomyces prevalansını histopatolojik bulgularla değerlendirmek ve Actinomyces'in alerjik rinit (AR), adenotonsiller hipertrofi (ATH) ve kronik tekrarlayan tonsillit (CRT) ile ilişkisini belirlemektir.

Gereç ve Yöntem: Adenoidektomi, bilateral tonsillektomi ve adenotonsillektomi uygulanan 228 hastanın histopatolojik kesitleri retrospektif olarak incelendi. Actinomyces varlığı, kriptit ve enflamasyonun şiddeti belirlendi. Veriler Statistical Package for the Social v.21.0 programı ile analiz edildi. İstatistiksel anlamlılık düzeyi $\mathrm{p}<0,05$ olarak kabul edildi.

Bulgular: Otuz dokuz $(\% 17,1)$ hastada Actinomyces saptandı. Actinomyces ATH ve CRT'de benzer bir oranda $(p=0,08)$, sırasıyla $\% 14,6$ ve $\% 24,6$ olarak görüldü. Actinomyces görülen tonsillerin çapı, olmayanlardan daha büyüktü $(p<0,01)$. Histopatolojik olarak Actinomyces'in görüldüğü tonsillerde kriptit sıklığı $(p=0,03)$ ve yüzey epitelindeki enflamasyon şiddeti $(p<0,01)$ artmıştı. Actinomyces, AR'li hastalarda AR olmayanlara göre daha sık bulunmuştur $(\mathrm{p}=0,02)$ (sırasıyla \%25,7 ve \%13).

Sonuç: Çalışmamız, adenotonsiller Actinomyces kolonizasyonunun ATH'ye, CRT ve AR'ye neden olabileceğini ve AR'nin ATH'nin etiyolojik faktörlerinden biri olabileceğini göstermektedir.

Anahtar Kelimeler: Actinomyces, adenotonsiller hipertrofi, alerjik rinit, rekürren tonsillit

Address for Correspondence: İlke Evrim SEÇiNTi MD, Hatay Mustafa Kemal University Tayfur Ata Sökmen Faculty of Medicine, Department of Pathology, Hatay, Turkey Phone: +90 5066899626 E-mail: ilkevrim@gmail.com ORCID ID: orcid.org/0000-0002-8614-3971

Received: 24.08.2020 Accepted: 22.12.2020

Presented in: This article was presented as an oral presentation (OP-075) at the International Medical Congress of İzmir Democracy University (IMCIDU'19) dated December 6-8, 2019.

${ }^{\circ}$ Copyright 2021 by the Tekirdağ Namık Kemal University Faculty of Medicine / Namık Kemal Medical Journal published by Galenos Publishing House. 


\section{INTRODUCTION}

Palatine, tubal, pharyngeal (adenoid) and lingual tonsils form Waldeyer ring, which is an important lymphatic structure of the upper airway'. Adenoidectomy and tonsillectomy are the most common surgical procedures in both pediatric and adult patients. The most common indications for surgery are adenotonsillar hypertrophy (ATH) and chronic recurrent tonsillitis (CRT), which may cause obstructive sleep-related breathing disorders ${ }^{2,3}$. Although the causes of ATH are still unclear, there are studies in the literature showing that allergy may be a risk factor ${ }^{4}$.

Actinomyces are Gram-positive, anaerobic, immobile, filamentous and rod-shaped commensal bacteria in the normal flora of the oropharyngeal, genitourinary and gastrointestinal tract ${ }^{5}$. They can resemble fungi because of their filamentous structure. In the literature, the incidence of Actinomyces in tonsil and adenoid has been reported in very variable rates, ranging from $0.3 \%$ to $40.7 \% 0^{2,5-9}$. There are different opinions on the role of Actinomyces in the etiology of tonsil/adenoid hypertrophy and CRT. In addition to the studies suggesting that Actinomyces plays a role as an etiologic agent in these pathologies ${ }^{7,9-12}$, there are also studies suggesting that it is only a saprophyte agent ${ }^{13}$. However, few studies have examined the histopathological effects of Actinomyces on tonsil and adenoid tissues $^{14,15}$. Allergic rhinitis (AR) is an inflammatory disease caused by IgE-mediated type 1 hypersensitivity reaction. AR has many factors in etiopathogenesis, including various fungi ${ }^{16}$. To date, no studies have investigated the relationship between AR and the presence of adenotonsillar Actinomyces in the literature. However, it is known that Actinomyces plays a role in the etiology of hypersensitivity pneumonia (extrinsic allergic alveolitis) ${ }^{17}$.

This study aims to determine the prevalence of Actinomyces in adenoidectomy, tonsillectomy and adenotonsillectomy materials, to investigate the relationship of Actinomyces with $A R, A T H$ and $C R T$, and to discuss all findings in the light of literature. This is the first study in the literature to investigate the relationship between AR and adenotonsillar Actinomyces.

\section{MATERIALS AND METHODS}

\section{Patient Selection}

This retrospective study included 228 patients who underwent adenoidectomy $(n=143)$, bilateral tonsillectomy $(n=29)$, and adenotonsillectomy $(n=56)$ at Silifke State Hospital between January 2013 and December 2015. The study were approved by the Hatay Mustafa Kemal University of Local Ethics Committee (protocol number: 10, date: 16.01.2020). Unilateral tonsillectomies were excluded because of different surgery indications. Data on age, sex, diagnosis of $A R$, indications for operation, the largest diameters of tonsils and adenoids were obtained from the patient files and pathology reports.

\section{Histopathological Evaluation}

Hematoxylin-eosin stained histopathological sections of a total of 369 tissue materials taken from 228 patients were re-evaluated on the Olympus BX53 (Olympus, Tokyo, Japan) light microscope and photographed with the Olympus DP20 digital imaging system (Olympus, Tokyo, Japan). Tonsillar Actinomycosis diagnosis is made either by the presence of sulfur granules in the form of a basophilic mass with a granular center and the radial fringes around it or by the presence of a unique Actinomyces filament in the tonsillar tissue and/or crypt $^{15}$ (Figure 1).

The presence of Actinomyces, cryptitis (evaluated only in palatine tonsils because there was no crypt in adenoid tissue), inflammation in the surface epithelium and lymphoid hyperplasia were re-evaluated. Inflammation in the surface epithelium was scored semiquantitatively as 0 : none, 1: mild, 2: moderate, and 3: severe. Lymphoid hyperplasia was classified as follicular hyperplasia, paracortical hyperplasia and mixed hyperplasia (follicular + paracortical).

\section{Statistical Analysis}

All clinical, histopathological and demographic data obtained from this study were analyzed with Statistical Package for the Social (SPSS) v.21.0 software package program (SPSS Inc, Armonk, NY, US). The Pearson chi-square test was used for the analysis of qualitative data. For quantitative data that were not normally distributed were statistically analyzed with the KolmogorovSmirnov and the Mann-Whitney U tests. Correlation analyses were performed with the Spearsman's rank correlation test. Statistical significance was accepted as $p<0.05$ in all analyses.

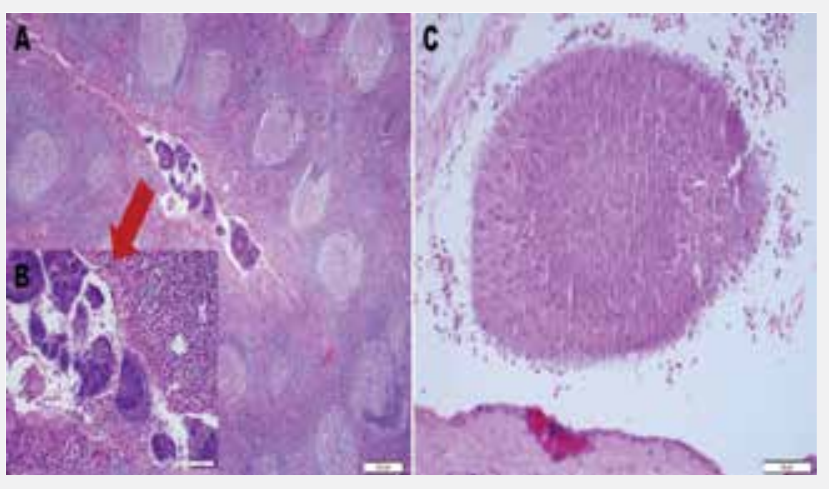

Figure 1. A) Irregularly shaped Actinomyces colonies in the tonsil crypt (hematoxylin-eosin, x200). B) On higher power, characteristic sulfur granules of Actinomyces (hematoxylineosin, $x 400$ ). C) Filamentous branching of the bacteria at the periphery of the colonies (hematoxylin-eosin, x400) 


\section{RESULTS}

The median age of all patients $(n=228)$ was $8 \pm 5.06$ years (minimum: 4, maximum: 39$) .132$ of them were male (57.9\%) and 96 were female (42.1\%). Actinomyces was detected in 39 patients (17.1\%). Actinomyces was seen in 29 (34.1\%) of 85 patients with tonsillectomy when adenoidectomy was excluded. The incidence of Actinomyces was similar in both sexes $(p=0.20)$. The median age of the patients with Actinomyces was higher than that of those without Actinomyces $(p<0.01)$. The median age of the patients with Actinomyces was $11 \pm 7.8$ years and the median age of the patients without Actinomyces was $8 \pm 3.6$ years. Actinomyces was seen in $25(14.6 \%)$ of 171 patients who underwent surgery for ATH and in $14(24.6 \%)$ of 57 patients who had surgery for CRT, and no significant difference was observed $(p=0.08)$. The diameters of the tonsils (palatine + pharyngeal) with Actinomyces were larger than those without
Actinomyces $(p<0.01)$. Histopathologically, cryptitis was observed more frequently in tonsils with Actinomyces $(\mathrm{p}=0.03)$ and the degree of inflammation in the surface epithelium was increased $(p<0.01)$. There was no difference in lymphoid hyperplasia types $(p=0.45)$. Follicular hyperplasia was high in both groups. Comparison of the presence of Actinomyces with other data and statistical test results are summarized in Table 1. Actinomyces was localized only in the right tonsil in 11 (28.8\%) of 39 patients with Actinomyces. Other localizations of Actinomyces are shown in Table 2.

Actinomyces was observed in $19(25.7 \%)$ of 74 patients with AR, while 20 (13\%) of 154 patients without AR had Actinomyces, and the difference was statistically significant $(p=0.02)$. The diagnosis of AR was higher in patients operated for ATH than in patients operated for CRT $(p=0.013)$. Adenoid diameters of patients with $A R$ were larger than those without $A R(p=0.046)$.

Table 1. Presence of Actinomyces and comparison of other data

\begin{tabular}{|c|c|c|c|}
\hline & $\begin{array}{l}\text { Actinomyces (-) } \\
\text { n (\%) }\end{array}$ & $\begin{array}{l}\text { Actinomyces (+) } \\
\text { n (\%) }\end{array}$ & $p$ value \\
\hline $\begin{array}{l}\text { Gender } \\
\text { Male } \\
\text { Female }\end{array}$ & $\begin{array}{l}113(85.6) \\
76(79.2)\end{array}$ & $\begin{array}{l}19(14.4) \\
20(20.8)\end{array}$ & 0.20 \\
\hline $\begin{array}{l}\text { Age (median) } \\
\text { Allergic rhinitis } \\
\text { No } \\
\text { Yes }\end{array}$ & $\begin{array}{l}8 \\
134(87) \\
55(74.3)\end{array}$ & $\begin{array}{l}11 \\
20(13) \\
19(25.7)\end{array}$ & $\begin{array}{l}<0.01 \\
0.02\end{array}$ \\
\hline $\begin{array}{l}\text { Indication for surgery } \\
\text { Adenotonsillar hypertrophy } \\
\text { Chronic recurrent tonsillitis }\end{array}$ & $\begin{array}{l}146(85.4) \\
43(75.4)\end{array}$ & $\begin{array}{l}25(14.6) \\
14(24.6)\end{array}$ & 0.08 \\
\hline $\begin{array}{l}\text { Type of surgery } \\
\text { Adenoidectomy } \\
\text { Tonsillectomy } \\
\text { Adenotonsillectomy }\end{array}$ & $\begin{array}{l}133(93) \\
15(51.7) \\
41(73.2)\end{array}$ & $\begin{array}{l}10(7) \\
14(48.3) \\
15(26.8)\end{array}$ & $<0.01$ \\
\hline $\begin{array}{l}\text { The largest diameter of the right tonsil (cm-median) } \\
\text { The largest diameter of the left tonsil ( } \mathrm{cm} \text {-median) } \\
\text { The largest diameter of the adenoid (cm-median) }\end{array}$ & $\begin{array}{l}3 \\
2.5 \\
2.5\end{array}$ & $\begin{array}{l}4 \\
4 \\
4\end{array}$ & $\begin{array}{l}<0.01 \\
<0.01 \\
<0.01\end{array}$ \\
\hline $\begin{array}{l}\text { Histopathological findings } \\
\text { Presence of cryptitis } \\
(-) \\
(+)\end{array}$ & $\begin{array}{l}23(82.1) \\
33(57.9)\end{array}$ & $\begin{array}{l}5(17.9) \\
24(42.1)\end{array}$ & 0.03 \\
\hline $\begin{array}{l}\text { The intensity of inflammation in the surface epith } \\
\text { None } \\
\text { Mild } \\
\text { Moderate } \\
\text { Severe }\end{array}$ & $\begin{array}{l}56(91.8) \\
65(87.8) \\
58(76.3) \\
10(58.8)\end{array}$ & $\begin{array}{l}5(8.2) \\
9(12.2) \\
18(23.7) \\
7(41.2)\end{array}$ & $<0.01$ \\
\hline $\begin{array}{l}\text { Types of lymphoid hyperplasia } \\
\text { Follicular hyperplasia } \\
\text { Paracortical hyperplasia } \\
\text { Mixed hyperplasia }\end{array}$ & $\begin{array}{l}124(84.9) \\
20(83.3) \\
45(77.6)\end{array}$ & $\begin{array}{l}22(15.1) \\
4(16.7) \\
13(22.4)\end{array}$ & 0.45 \\
\hline Total & $189(82.9)$ & $39(17.1)$ & 228 \\
\hline
\end{tabular}




\section{Table 2. Actinomyces localizations}

\begin{tabular}{|l|l|}
\hline Actinomyces localization & $\mathbf{n}(\%)$ \\
\hline Right tonsil & $11(28.2)$ \\
\hline Left tonsil & $7(17.9)$ \\
\hline Pharyngeal tonsil (adenoid) & $10(25.6)$ \\
\hline Both tonsils & $5(12.8)$ \\
\hline Right tonsil + adenoid & $2(5.1)$ \\
\hline Left tonsil + adenoid & $2(5.1)$ \\
\hline Both tonsils + adenoid & $2(5.1)$ \\
\hline
\end{tabular}

\section{DISCUSSION}

Actinomyces spp. are found in normal flora of the oropharyngeal, genitourinary and gastrointestinal tract $^{5}$. Histopathological examination is more valuable than microbiological culture in the diagnosis of Actinomyces $^{18}$. There is a wide range in the literature regarding the frequency of tonsillar Actinomycosis ranging from 0.3\% to 40.7\%. We wanted to investigate the incidence of Actinomyces in our series. Coban et al. ${ }^{2}$ found only $3(0.3 \%)$ Actinomyces in 1,078 tonsillectomy cases. Riffat and Walker ${ }^{6}$ found 221 (18.2\%) Actinomyces of 1,213 tonsillectomy cases. Ashraf et al. ${ }^{5}$ found 83 (40.7\%) Actinomyces of 204 tonsillectomy cases. We found Actinomyces at the rate of 17.1\% $(n=36)$ in our series. Since Actinomyces is found as saprophyte in oral flora, the general opinion is that it is also found as saprophyte in tonsils. Therefore, there may be different attitudes among pathologists to specify tonsillar Actinomyces in the report and this may lead to differences in the results of retrospective studies using the archive of reports. In fact, if only pathology reports were taken as the basis in our study, Actinomyces was reported in 11 (4.8\%) of 228 patients, but when preparations were re-evaluated, the number of patients with Actinomyces was revised to $39(17.1 \%)$. In some studies, it was reported that tonsillar Actinomycosis was seen more frequently in adults than in children ${ }^{5,11,12,19,20}$, particularly in older children ${ }^{5,21}$. Some studies have shown that Actinomycosis is not age-related ${ }^{15,22}$. In this study, the median age value (median age: 11) of those with Actinomyces colony was greater than that of those without Actinomyces (median age: 8 years) $(p<0.01)$.

In most of the studies in the literature, the rate of tonsillar Actinomycosis was found to be similar in both sexes $5,15,21,22$. Similar findings were obtained in this study, which is consistent with the literature.

The role of Actinomyces in the etiology of ATH and CRT remains unclear. In addition to the studies suggesting that Actinomyces has a role in the etiology of hypertrophy and recurrent tonsillitis ${ }^{7,10-12,23}$, there are also studies suggesting that it is not associated with these diseases $5,11,13,24$. In the study of Kutluhan et al. ${ }^{15}$, Actinomyces was found in 33.3\% of tonsils and it was revealed that Actinomyces was more common in tonsillar hypertrophy
$(61.5 \%)$ than in recurrent tonsillitis (21.9\%). Besides, they found that the volume of tonsils found in Actinomyces was larger than in those without Actinomyces. Similarly, Daneshmandan et al. ${ }^{22}$ found that tonsil volumes with Actinomyces (mean 8.65 $\mathrm{mL}$ ) were larger than in those without Actinomyces (mean 4.48 $\mathrm{mL}$ ). In contrast to these studies, Jones et al. ${ }^{25}$ found a negative correlation between tonsillar Actinomyces colonization and hypertrophy and found a higher rate of Actinomyces in patients with recurrent tonsillitis compared to hypertrophy patients. Toh et al. ${ }^{11}$ reported that Actinomyces did not affect the tonsillar size. In this study, a similar rate of actinomyces was detected in patients operated for hypertrophy and recurrent tonsillitis $(p=0.08)$. The diameters of the tonsils (palatine and pharyngeal tonsils) with Actinomyces were larger than in those without Actinomyces $(\mathrm{p}<0.01)$, suggesting that Actinomyces plays a role in the etiology of ATH. Tonsils with Actinomyces showed more cryptitis $(p=0.03)$ and inflammation in the surface epithelium was more severe $(p<0.01)$. This suggests that Actinomyces may be an effective pathogen in the etiology of recurrent tonsillitis.

$A R$ is one of the most common chronic diseases in children ${ }^{26}$. Few studies have investigated the relationship between $A R$ and $A H$ and there is no consensus between these studies. Sadeghi-Shabestari et al. ${ }^{27}$ found a significant correlation between positive skin prick test and high serum IgE levels with ATH. Modrzynski and Zawisza ${ }^{28}$ also reported that $\mathrm{AR}$ might cause $\mathrm{AH}$. Similarly, Bozkurt et al. ${ }^{29}$ found that adenoid volumes of patients with $A R$ were higher than those of patients without AR. In contrast to these studies argueing that $\mathrm{AR}$ causes $\mathrm{AH}$ or exacerbates existing $\mathrm{AH}$, Ameli et al. ${ }^{30}$ found that patients with $A R$ had smaller adenoid volumes than those without $A R$, suggesting that anterior nasal obstruction stopped adenoid growth. In our study, the adenoid size was higher in patients with $A R(p=0.046)$ and there was a positive correlation between them $(p=0.04)$. Our findings support the view that $A R$ may cause or increase existing $\mathrm{AH}$, as in the studies of SadeghiShabestari et al. ${ }^{27}$ and Modrzynski and Zawisza ${ }^{28}$. Some fungi have been reported to play a role in the etiology of $A R$ in the literature. In their study, Namyslowski et al. ${ }^{16}$ found Candida albicans in $3.8 \%$, Aspergillus fumigatus in 11.5\%, Alternaria alternata in $3.8 \%$, Mucor racemosus in 7.6\% and Cladosporum herbarum in $7.6 \%$ in patients with AR. Actinomyces is also known to be similar to fungi because of their filamentous structure, and Actinomyces like Aspergillus have been shown to act as active pathogens in allergic diseases such as hypersensitivity pneumonia ${ }^{17}$. In our study, Actinomyces was found to be more frequent in patients with $A R$ (25.7\% and $13 \%$, respectively) than in those without $A R$, and there was a positive correlation between them $(p=0.02)$.

\section{Study Limitations}

Our study's retrospective design and therefore, the lack of access to drug history and laboratory values of all patients constitute the limitations of our study. 


\section{CONCLUSION}

ATH and recurrent tonsillitis, which can cause obstructive sleeprelated respiratory disorders, are the most common diseases and adenotonsillectomy is one of the most common surgical procedures in the treatment of these diseases. However, the etiologic cause of ATH is still unclear. Our study shows that adenotonsillar Actinomyces colonization may cause ATH, recurrent tonsillitis, and $A R$. It also suggests that $A R$ may be involved in the etiology of ATH. Establishing causal relationships will contribute to the development of both preventive and therapeutic approaches. Our study is the first study to investigate the relationship between AR and Actinomyces.

\section{Ethics}

Ethics Committee Approval: The study were approved by the Hatay Mustafa Kemal University of Local Ethics Committee (protocol number: 10, date: 16.01.2020).

Informed Consent: Consent form was filled out by all participants.

\section{Peer-review: Externally peer-reviewed.}

Financial Disclosure: The author declared that this study received no financial support.

\section{References}

1. Tan GC, Stalling M, Al-Rawabdeh $S$, Kahwash BM, Alkhoury RF, Kahwash SB. The spectrum of pathological findings of tonsils in children: A clinicopathological review. Malays J Pathol. 2018;40:11-26.

2. Coban K, Aydın E, Inal S, Ozluoglu LN. Review of 1078 tonsillectomy: Retrospective cohort study. J Surg Med. 2018;2:91-5.

3. Baugh RF, Archer SM, Mitchell RB, Rosenfeld RM, Amin R, Burns JJ, et al. Clinical practice guideline: tonsillectomy in children. Otolaryngol Head Neck Surg. 2011;144:1-30.

4. Cho KS, Kim SH, Hong SL, Lee J, Mun SJ, Roh YE, et al. Local Atopy in Childhood Adenotonsillar Hypertrophy. Am J Rhinol Allergy. 2018;32:160-6.

5. Ashraf MJ, Azarpira N, Khademi B, Hashemi B, Shishegar M. Relation between Actinomycosis and Histopathological and Clinical Features of the Palatine Tonsils: An Iranian Experience. Iran Red Crescent Med J. 2011;13:499-502.

6. Riffat $F$, Walker P. Prevalence of tonsillar Actinomyces in children undergoing tonsillectomy for sleep disordered breathing compared with recurrent tonsillitis. Int J Pediatr Otorhinolaryngol. 2009;73:1111-3.

7. Hasan M, Kumar A. Actinomycosis and tonsillar disease. BMJ Case Rep. 2011;2011:bcr0120113750.

8. Rebechi G, Pontes TE, Braga EL, Matos WM, Rebechi F, Matsuyama C. Are histologic studies of adenotonsillectomy really necessary? Int Arch Otorhinolaryngol. 2013;17:387-9.

9. Essa R, Maharaj $S$, Hari K, Motakef S. Tonsil histopathology in HIV-infected versus HIV-uninfected adults. South Afr J HIV Med. 2019;20:936.

10. Kalaiarasi R, Subramanian KS, Vijayakumar C, Venkataramanan R. Microbiological Profile of Chronic Tonsillitis in the Pediatric Age Group. Cureus. 2018;10:e3343.
11. Toh ST, Yuen HW, Goh YH. Actinomycetes colonization of tonsils: a comparative study between patients with and without recurrent tonsillitis. J Laryngol Otol. 2007;121:775-8.

12. Kansu L. Relation of Actinomyces with Tonsillar Hypertrophy and Antibiotic Use. Turk Arch Otorhinolaryngol. 2017;55:17-21.

13. Gaffney $R$, Harrison $M$, Walsh $M$, Sweeney $E$, Cafferkey M. The incidence and role of actinomyces in recurrent acute tonsillitis. Clin Otolaryngol Allied Sci. 1993;18:268-71.

14. Gysin C. Indications of pediatric tonsillectomy. ORL J Otorhinolaryngol Relat Spec. 2013;75:193-202.

15. Kutluhan A, Salviz M, Yalcıner G, Kandemir O, Yesil C. The role of the actinomyces in obstructive tonsillar hypertrophy and recurrent tonsillitis in pediatric population. Int J Pediatr Otorhinolaryngol. 2011;75:391-4.

16. Namysłowski G, Rogala B, Mrówka-Kata K, Ponińska-Polańczuk J. Rola grzybów niedoskonałych $w$ etiopatogenezie całorocznego alergicznego niezytu nosa [The role of imperfect fungi in etiopathogenesis of allergic rhinitis]. Otolaryngol Pol. 1998;52:277-80.

17. Baur X, Fischer A, Budnik LT. Spotlight on the diagnosis of extrinsic allergic alveolitis (hypersensitivity pneumonitis). J Occup Med Toxicol. 2015;10:15.

18. Pransky SM, Feldman JI, Kearns DB, Seid AB, Billman GF. Actinomycosis in obstructive tonsillar hypertrophy and recurrent tonsillitis. Arch Otolaryngol Head Neck Surg. 1991;117:883-5.

19. Bhargava D, Bhusnurmath $B$, Sundaram KR, Raman R, Al Okbi HM, Al Abri $R$, et al. Tonsillar actinomycosis: a clinicopathological study. Acta Trop. 2001;80:163-8.

20. Aydin A, Erkiliç S, Bayazit $Y A$, Koçer NE, Ozer E, Kanlikama M. Relation between actinomycosis and histopathological and clinical features of the palatine tonsils: a comparative study between adult and pediatric patients. Rev Laryngol Otol Rhinol (Bord). 2005;126:95-8.

21. Altun E, Erbek ND, Tane IE, Colak AH, Turan G. Does tonsil hypertrophy ocur as a result colonization of actinomycosis? Med Science. 2019;1-4.

22. Daneshmandan N, Yarmohammadi M, Izadi P. Prevalence of tonsillar actinomycosis in tonsillectomy specimens; clinical importance and management. J Pediatr Res. 2019;6:135-40.

23. Lord F. The etiology of actinomycosis the presence of actınomycetes in the contents of carlous teeth and the tonsillar crypts of patients without actinomycosis. JAMA. 1910;55:1261-3.

24. van Lierop $A C$, Prescott $C A$, Sinclair-Smith $C C$. An investigation of the significance of Actinomycosis in tonsil disease. Int J Pediatr Otorhinolaryngol. 2007;71:1883-8.

25. Jones GH, Burnside G, McPartland J, Markey A, Fallon M, De S. Is tonsillectomy mandatory for asymmetric tonsils in children? A review of our diagnostic tonsillectomy practice and the literature. Int J Pediatr Otorhinolaryngol. 2018;110:57-60.

26. Wright AL, Holberg $C J$, Martinez $F D$, Halonen $M$, Morgan $W$, Taussig LM. Epidemiology of physician-diagnosed allergic rhinitis in childhood. Pediatrics. 1994;94:895-901.

27. Sadeghi-Shabestari $M$, Jabbari Moghaddam $Y$, Ghaharri $H$. Is there any correlation between allergy and adenotonsillar tissue hypertrophy? Int J Pediatr Otorhinolaryngol. 2011;75:589-91.

28. Modrzynski M, Zawisza E. An analysis of the incidence of adenoid hypertrpohy in allergic children. Int J Pediatr Otorhinolaryngol. 2007;71:713-9.

29. Bozkurt G, Dizdar SK, Korkut AY, Coskun BU. Adenoid vegetation in children with allergic rhinitis. Turk Arch Otorhinolaryngol. 2015;53:168-72.

30. Ameli F, Brocchetti F, Tosca MA, Signori A, Ciprandi G. Adenoidal hypertrophy and allergic rhinitis: is there an inverse relationship? Am J Rhinol Allergy. 2013;27:5-10. 